\title{
CORRELATION ANALYSIS IN DIFFERENT PLANTING DATES OF RAPESEED VARIETIES
}

\author{
V. Rameeh $^{1}$
}

\begin{abstract}
The present study was aimed at finding out the planting dates effects on yield associated traits and also determining the variations of correlations among the traits in different planting dates of rapeseed genotypes. Significant planting dates and genotypes effects for phenological traits, yield components, seed yield and oil percentage revealed significant differences of planting dates and genotypes for these traits. Plant height had positive effect on pods per plant by increasing number of branches in each plant and length of main raceme. 1000-seed weight had significant positive correlation with seed yield, so any changes for this trait had considerable effect on seed yield. The variation of correlation between duration of flowering and pods per plant was less than the correlation of duration of flowering to other traits in different planting dates, so it can be used as selection breeding criterion.
\end{abstract}

Keywords: breeding criterion, phenological traits, variation, yield components.

\section{INTRODUCTION}

Rapeseed (Brassica napus L.) is now one of the most important oil crops in the world. For improving of seed yield of rapeseed and other brassica species, the important breeding strategies are understanding and utilization of genetic, physiological and morphological basis of yield associated traits in different environmental conditions. Determining suitable planting date plays has important role in conformation of plant growth stages with desirable environmental conditions which results in maximum yield. Planting date has a considerable effect on seed yield by influencing the yield components so that late planting decreases the most important traits i.e. days to flowering, duration of lowering, plant height and pods per plant which cause a remarkable reduction in seed yield
(Sharief and Keshta, 2002; Siadat and Hemayati, 2009). Development of ideotype varieties with minimum reduction of yield components and seed yield in different environmental conditions such as planting dates is an important goal of plant breeders. The ideotype concept provides opportunity to define the desired high-yield phenotype in terms of several relatively simple plant characters (Thurling, 1991). Seed yield is a complex character that can be determined by several components reflecting positive or negative effects upon this trait, whereas it is important to examine the contribution of each of the various components in order to give more attention to those having the greatest influence on seed yield (Khaliq et. al., 2001; Khan et. al., 2003; Sagir et. al.,2004; Mahasi et. al., 2006; Agahi, et.

al., 2007; Burhan, 2007; MarjanovicJeromela, et. al., 2007). 
Therefore, knowing the relationship among the quantitative traits with the seed yield in different environmental conditions make breeding programs and their success more optimistic and secure (Sharief and Keshta, 2002; Marjanovic-Jeromela, et. al., 2009). The response of seed yield to direct selection also may be unpredictable, therefore plant breeders needs to examine the relationships among various traits, especially between seed yield and other traits. As the number of independent variables influencing a particular dependent variable a certain amount of interdependence is expected among the independent variables (Aytac and Kinaci, 2008; Ogrodowczyk and Warzyniak, 2004; Sabaghnia, et. al., 2010; Scheiner et. al., 2000; Wiliams et. al., 1990). Different statistical techniques have been used in modeling crops yield, including correlation, regression, path analysis, factor analysis, factor components and cluster analysis (Leilah and Al-Khateeb, 2005; Akbar et. al., 2007). In experiment with nine summer rapeseed, Chango and McVetty (2001) observed that total dry matter and harvest index had a significant correlation with grain yield, but there was no correlation between chlorophyll or water use efficiency. Ali et al. (2003) also showed that pods per plant and 1000-seed weight had significant correlation with seed yield. Days to flowering and number of pods per plant were correlated significantly with seed yield (Khan et. al., 2006). Also a significant correlation was observed between pod number per plant and seed yield in species of $B$. napus and B. juncea (Akbar et. al., 2007; Marjanovic-Jeromela, et. al., 2009). This showed that among yield component number of pods had greatest and seed per pod and seed weight had weak influence on seed yield. Significant correlations between yield and yield associated traits were also reported in other important crops (Alishah, et. al., 2008; Farshadfar and Farshadfar, 2008; Khalily, et. al., 2010; Azeez and Morakinyo, 2011; Belete, 2011; Hefny, 2011).

Although in planting date studies of rapeseed and other brassica species, correlation among the yield associated traits were noticed but in a few studies the variations of correlations among the traits were stressed. The objectives of the present study were to detect the planting date effects on yield associated traits and also to estimate the variations the correlation between the traits in different planting dates to identify suitable selection criteria based on correlation analysis.

\section{MATERIALS AND METHODS}

In order to evaluation of planting dates effects on yield associated traits and variations of correlations in rapeseed varieties, a split-plot experiment based on randomize complete block design with four replications was conducted at Biekol Agriculture Research Station, located in Neka, Iran $\left(53^{\circ}, 13^{\prime} \mathrm{E}\right.$ longitude and $36^{\circ}$ $43^{\prime} \mathrm{N}$ latitude, $15 \mathrm{~m}$ above sea level) during two cropping seasons (2003-04 and 2004-05). Five planting dates including 29 September, 9 October, 19 October, 29 October and 8 November were considered as main plots and the cultivars including Hyola401, Option500 and RGS003 were also considered as sub- plots.

The soil was classified as a deep loam soil (Typic Xerofluents, USDA classification) contained an average of $280 \mathrm{~g}$ clay $\mathrm{kg}^{-1}$,

$560 \mathrm{~g}$ silt $\mathrm{kg}^{-1}, 160 \mathrm{~g}$ sand $\mathrm{kg}^{-1}$, and 22.4 g organic matter $\mathrm{kg}^{-1}$ with a $\mathrm{pH}$ of $7.3 \mathrm{Each}$ sub plot was consisted of four rows $5 \mathrm{~m}$ long and $30 \mathrm{~cm}$ apart. The distance between plants on each row was $5 \mathrm{~cm}$ resulting in approximately 400 plants per 
plot, which were sufficient for statistical analysis. Crop management factors like land preparation, crop rotation, fertilizer, and weed control were followed as recommended for local area.

All the plant protection measures were adopted to make the crop free from insects. The data were recorded on ten randomly selected plants of each entry of each replication for days to flowering, duration of flowering, plant height, pods per plant, seeds per pod and 1000-seed weight.Seed yield (adjusted to $\mathrm{kg} / \mathrm{ha}$ ) was recorded based on two middle rows of each plot. Oil content was estimated with the help of nuclear magnetic resonance spectrometry (Madson, 1976). Combined analyses of variance of split-plot experiment were done for all the traits (Steel et. al., 1997). All statistical analyses were carried out using SAS soft ware.

\section{RESULTS AND DISSCSION}

Significant mean squares of planting dates and genotypes for phenological traits, plant height, yield components, seed yield and oil percentage revealed significant differences of planting date for these traits and also the genotypes had significant genetic differences (Table 01). Non significant mean squares of interaction effects of planting dates and genotypes were detected for plant height, pods per plant, seed yield and oil percentage.

Due to late planting, days to flowering was increased and duration of floweringwas decreased because of moderate temperature in first and second planting dates and decreasing of temperature in the late planting (Table 02).

Plant height was varied from 155.35 to $186.15 \mathrm{~cm}$ in first planting date and first year in Hyola401 and Option500, respectively and also due to late planting, plant height of all the genotypes were decreased in the first and second years under study. The high number of pods per plant was related to Hyola401 and RGS003 in the first planting date and second year and also the low number of this trait also was detected in RGS003 in the fourth and fifth planting dates in second year (Table 02).

In the most of planting dates, the highest and lowest number of seeds per pods was detected in Hyola401 and Option500, respectively. Hyola401 had the highest 1000-seed weight in the most of the planting dates. The highest and lowest seed yield were related to Hyola401 and Option500 in most of the planting dates in two years under study and also it was varied from 4355 to $2017.50 \mathrm{~kg} / \mathrm{ha}$ in Hyola401 and RGS003, respectively. In most of planting dates the high oil content was related to Hyola401.

The result of Pearson correlation coefficient among the traits is presented in Table 03. Significant negative average correlation $(-0.92 * *)$ was observed between days to flowering and duration of flowering and it was significant for all of planting dates.

Significant negative average correlation was detected between days to flowering and pods per plant and also it was significant from second to fifth planting dates.

Significant positive average correlation was determined between duration of flowering and pods per plant and it was significant and positive for all of the planting dates. Positive correlation was observed between duration of flowering and seed yield and also it was significant 
in third and fifth planting dates. Significant positive correlation was determined between plant height and pods per plant in two planting dates. flowering, plant height and yield components and seed yield in rapeseed (Sharief and Keshta, 2002; Siadat and Hemayati, 2009).

\section{Table 01: Combined analysis of variance for phenologlical traits, plant height, yield components, seed yield and oil content.}

\begin{tabular}{|c|c|c|c|c|c|c|c|c|c|}
\hline \multirow[t]{2}{*}{ S.O.V } & \multirow[t]{2}{*}{ df } & & \multicolumn{7}{|c|}{ (F-test) } \\
\hline & & $\begin{array}{l}\text { Days to } \\
\text { flowering }\end{array}$ & $\begin{array}{c}\text { Duration } \\
\text { of } \\
\text { flowering }\end{array}$ & $\begin{array}{c}\text { Plant } \\
\text { height }\end{array}$ & $\begin{array}{l}\text { Pods per } \\
\text { Plant }\end{array}$ & $\begin{array}{l}\text { Seeds per } \\
\text { Pod }\end{array}$ & $\begin{array}{c}\text { 1000-Seed } \\
\text { Weight }\end{array}$ & Seed yield & Oil\% \\
\hline Year(Y) & 1 & 0.48 & $1430.23 * *$ & $46.55 * *$ & 1.21 & $13.66 * *$ & $13.66 * *$ & 1.96 & 0.00 \\
\hline $\operatorname{Rep} / \mathrm{Y}$ & 6 & - & - & - & - & - & - & - & - \\
\hline Planting date(D) & 4 & $1215.13^{* *}$ & $3115.40 * *$ & $50.89 * *$ & $48.89 * *$ & $6.00 * *$ & $6.00 * *$ & $9.27 * *$ & $17.22 * *$ \\
\hline YxD & 4 & $90.89 * *$ & $396.66 * *$ & 1.21 & $15.05^{* *}$ & $4.96 * *$ & $4.96 * *$ & 0.56 & 0.09 \\
\hline Error(a) & 24 & - & - & - & - & - & - & - & - \\
\hline Variety(V) & 2 & $2291.88^{* *}$ & $1320.13 * *$ & $86.46 * *$ & $4.61^{*}$ & $15.04 * *$ & $15.04 * *$ & $38.67 * *$ & $38.38 * *$ \\
\hline$Y \times V$ & 2 & $97.61 * *$ & $95.05 * *$ & $16.07 * *$ & 2.07 & 1.13 & 1.13 & 3.07 & 0.02 \\
\hline $\mathrm{D} \times \mathrm{V}$ & 8 & $241.62 * *$ & $153.78 * *$ & 2.46 & 1.07 & $2.51 *$ & $2.51^{*}$ & 1.44 & 1.61 \\
\hline$Y \times D \times V$ & 8 & $11.00 * *$ & $9.77 * *$ & 2.56 & $3.39 * *$ & $5.26 * *$ & $5.26 * *$ & 1.08 & 0.18 \\
\hline Error (b) & 84 & - & - & - & - & - & - & - & - \\
\hline
\end{tabular}

$*, * *$ Significant at $\mathrm{p}=0.05$ and 0.01 , respectively.

Pods per plant had significant positive correlation with seed yield only in third planting date. Seeds per pod had significant positive was significant correlation with seed yield only in first planting date. 1000-seed weight had significant positive average correlation with seed yield and also it from third to fifth planting dates.

Significant positive correlation was determined between seed yield and oil content in fourth and fifth planting dates.Significant planting dates and genotypes effects for all the studied traits revealed significant differences of planting dates and genotypes for these traits.

Significant planting dates effects were reported for days to flowering, duration of
Non significant interaction effects of planting dates and genotypes for plant height, pods per plant, seed yield and oil percentage, indicated the same trend of variation of the genotypes for these traits in different planting dates. 
Table 03: Pearson correlation among the traits in different planting dates.

\begin{tabular}{|c|c|c|c|c|c|c|c|c|c|}
\hline Traits & Planting dates & $\begin{array}{l}\text { Days to } \\
\text { flowering }\end{array}$ & $\begin{array}{c}\text { Duration } \\
\text { of } \\
\text { flowering }\end{array}$ & $\begin{array}{l}\text { Plant } \\
\text { height }\end{array}$ & $\begin{array}{c}\text { Pods per } \\
\text { Plant }\end{array}$ & $\begin{array}{l}\text { Seeds per } \\
\text { Pod }\end{array}$ & $\begin{array}{c}1000- \\
\text { Seed } \\
\text { Weight }\end{array}$ & Seed yield & Oil\% \\
\hline \multirow{7}{*}{$\begin{array}{l}\text { Days to } \\
\text { flowering }\end{array}$} & 29 September & 1 & $-0.96^{\star *}$ & 0.38 & -0.43 & -0.28 & -0.32 & $-0.58^{*}$ & 0.01 \\
\hline & 9 October & 1 & $-0.93^{* *}$ & -0.29 & -0.54 & -0.24 & $-0.79^{\star *}$ & -0.29 & 0.11 \\
\hline & 19 October & 1 & $-0.93^{\star *}$ & -0.11 & $-0.64^{*}$ & -0.41 & $-0.79^{\star *}$ & $-0.71^{* *}$ & 0.06 \\
\hline & 29 October & 1 & $-0.88^{* *}$ & -0.11 & $-0.59^{*}$ & 0.01 & $-0.62^{*}$ & $-0.73^{* *}$ & -0.39 \\
\hline & 8 November & 1 & $-0.90^{\star *}$ & 0.00 & $-0.77^{\star *}$ & -0.01 & -0.52 & -0.50 & -0.50 \\
\hline & average & & $-0.92^{\star \star}$ & -0.03 & $-0.59^{\star}$ & -0.19 & $-0.61^{*}$ & -0.56 & -0.14 \\
\hline & Variance & & 0.00 & 0.06 & 0.02 & 0.03 & 0.04 & 0.03 & 0.08 \\
\hline \multirow{7}{*}{$\begin{array}{l}\text { Duration of } \\
\text { flowering }\end{array}$} & 29 September & & 1 & -0.26 & $0.57^{\star}$ & 0.18 & 0.18 & 0.45 & 0.17 \\
\hline & 9 October & & 1 & 0.45 & $0.76^{\star *}$ & 0.13 & $0.66^{*}$ & 0.35 & -0.04 \\
\hline & 19 October & & 1 & 0.42 & $0.83^{* *}$ & 0.14 & $0.76^{* *}$ & $0.64^{*}$ & -0.21 \\
\hline & 29 October & & 1 & 0.52 & $0.80^{\star *}$ & -0.29 & 0.50 & 0.51 & 0.46 \\
\hline & 8 November & & 1 & 0.26 & $0.90^{* *}$ & -0.15 & 0.30 & $0.58^{*}$ & 0.55 \\
\hline & average & & & 0.28 & $0.77^{\star \star}$ & 0.00 & 0.48 & 0.51 & 0.19 \\
\hline & Variance & & & 0.10 & 0.02 & 0.04 & 0.06 & 0.01 & 0.11 \\
\hline \multirow{7}{*}{ Plant height } & 29 September & & & 1 & 0.40 & $-0.71^{\star *}$ & $-0.68^{* *}$ & $-0.88^{* *}$ & -0.05 \\
\hline & 9 October & & & 1 & $0.60^{*}$ & 0.11 & -0.06 & -0.12 & -0.34 \\
\hline & 19 October & & & 1 & 0.53 & -0.53 & 0.18 & -0.21 & -0.62 \\
\hline & 29 October & & & 1 & $0.73^{\star \star}$ & -0.48 & -0.16 & -0.28 & 0.05 \\
\hline & 8 November & & & 1 & 0.43 & -0.48 & $-0.64^{*}$ & -0.03 & -0.16 \\
\hline & average & & & & 0.54 & -0.42 & -0.27 & -0.30 & -0.22 \\
\hline & Variance & & & & 0.02 & 0.10 & 0.14 & 0.11 & 0.07 \\
\hline \multirow{7}{*}{$\begin{array}{l}\text { Pods per } \\
\text { Plant }\end{array}$} & 29 September & & & & 1 & -0.31 & -0.12 & -0.20 & 0.44 \\
\hline & 9 October & & & & 1 & -0.07 & 0.11 & 0.27 & -0.05 \\
\hline & 19 October & & & & 1 & -0.10 & $0.64^{*}$ & $0.57^{*}$ & -0.16 \\
\hline & 29 October & & & & 1 & -0.48 & 0.22 & 0.26 & 0.33 \\
\hline & 8 November & & & & 1 & -0.12 & 0.15 & 0.45 & 0.49 \\
\hline & average & & & & & -0.22 & 0.20 & 0.27 & 0.21 \\
\hline & Variance & & & & & 0.03 & 0.08 & 0.09 & 0.09 \\
\hline
\end{tabular}

\footnotetext{
$*, * *$ Significant at $\mathrm{p}=0.05$ and 0.01 , respectively.
} 


\begin{tabular}{|c|c|c|c|c|c|}
\hline & Variance & 0.00 & 0.06 & 0.22 & 0.05 \\
\hline \multirow{7}{*}{$\begin{array}{c}\text { 1000-Seed } \\
\text { Weight }\end{array}$} & 29 September & & 1.00 & 0.54 & 0.27 \\
\hline & 9 October & & 1.00 & 0.42 & 0.10 \\
\hline & 19 October & & 1.00 & $0.58^{*}$ & 0.14 \\
\hline & 29 October & & 1.00 & $0.82^{\star *}$ & $0.73^{* *}$ \\
\hline & 8 November & & 1.00 & $0.61^{*}$ & $0.58^{*}$ \\
\hline & average & & 1.00 & $0.59^{\star}$ & 0.36 \\
\hline & Variance & & 0.00 & 0.02 & 0.08 \\
\hline \multirow{7}{*}{ Seed yield } & 29 September & & & 1.00 & -0.07 \\
\hline & 9 October & & & 1.00 & 0.53 \\
\hline & 19 October & & & 1.00 & 0.40 \\
\hline & 29 October & & & 1.00 & $0.63^{*}$ \\
\hline & 8 November & & & 1.00 & $0.84^{* *}$ \\
\hline & average & & & 1.00 & 0.47 \\
\hline & Variance & & & 0.00 & 0.11 \\
\hline
\end{tabular}

$*$, ** Significant at $\mathrm{p}=0.05$ and 0.01 , respectively.

Late planting had considerable effects on duration of flowering and plant height and these traits were decreased in the late planting dates. Due to decreasing effects of late planting dates on plant height and duration of flowering, pods per plant was decreased and finally it had decreasing effect on seed yield.

Among the yield components, seeds per pod and 1000-seed weight were less affected by late planting dates.

In earlier study (Siadat and Hemayati, 2009) were reported negligible effects of planting dates on seeds per pod and 1000seed weigh. Response of rapeseed oil content to changes in planting date was low and showed that this trait was controlled by genotypes rather than environmental effects.

High significant negative correlation between days to flowering and duration of flowering, indicating high temperature and short and long day in late planting dates had considerable decreasing effects on duration of flowering, therefore days to flowering had significant negative correlation with yield components and seed yield.

Significant positive correlation of duration of flowering with pods per plant, indicated due to increasing this trait pod formation was increased.

Duration of flowering had also positive effects on 1000-seed weight and seed yield. Plant height had positive effect on pods per plant by increasing number of branches in each plant and length of main raceme.

The variation of correlation between duration of flowering and pods per plant was less than the correlation of this trait to other traits in different planting dates, so it can be used as selection breeding 
criterion. Most of the correlations among the traits which were significant at $1 \%$ probability level had less variation in different planting dates.

The correlation between pods per plant and seed yield had maximum variation in different planting dates, therefore selection based on this trait for seed yield improving should be repeated in several conditions.

\section{AKNOWLEDGEMENT}

The author wish to thanks from Agricultural and Natural Resources Research Center of Mazandaran and Seed and Plant Improvement Institute (SPII) for providing genetic materials and facility for conducting the experiment.

\section{REFERENCES}

Agahi, K., H. M. Fotokian and E. Farshadfar, (2007). Correlation and Path Coefficient Analysis for Some Yield-Related Traits in Rice Genotypes (Oryza sativa L.). Asian J. of Plant Sci. 6: 513-517.

Akbar M, Saleem, U.T., Yaqub, M. and Iqbal, N. (2007). Utilization of genetic variability, correlation and path analysis for seed yield improvement in mustard, Brassica juncea L. J. Agric. Res., 45(1): 25-31.

Ali, N., Javidfar, F., Elmira, J.Y. and Mirza, M.Y. (2003). Relationship among yield components and selection criteria for yield improvement in winter rapeseed (Brassica napus L.). Pak. J. Bot. 35(2): 167-174.

Alishah, O., M.B. Bagherieh-Najjar and L. Fahmideh, (2008). Correlation, Path coefficient and factor analysis of some quantitative and agronomic traits in cotton (Gossypium hirsutum L.). Asian J. Biol. Sci. 1: 61-68.

Aytaç Z, G. Kinaci, and E. Kinaci. (2008). Genetic variation, heritability and path analysis of summer rapeseed cultivars, J. Appl. Biol. Sci. 2(3):35-39.

Azeez, M.A. and J.A. Morakinyo, (2011). Path Analysis of the Relationships Between Single Plant Seed Yield and Some Morphological Traits in Sesame (Genera Sesamum and Ceratotheca). Int. J. Plant Breed. Genet., 5: 358-368.

Belete, Y. S. (2011). Genetic Variability, Correlation and Path Analysis Studies in Ethiopian Mustard (Brassica carinata A. Brun) Genotypes. Int. J. Plant Breed. Genet., 5: 328-338.

Burhan, A. (2007). The Path Analysis of Yield and its Components in Safflower (Carthamus tinctorius L.). J. of Biol. Sci. 7: 668-672.

Chango, G. and P.B.E. McVetty. (2001). Relationship of physiological characters to yield parameters in oilseed rape. Canadian J. Pl. Sci.,81: 1-6.

Farshadfar, M. and E. Farshadfar. (2008). Genetic Variability and Path Analysis of Chickpea (Cicer arientinum L.) Landraces and Lines. J. Appl. Sci., 8: 3951-3956. 
Hefny, M. (2011). Genetic parameters and path analysis of yield and its components in corn inbred lines (Zea mays L.) at different sowing dates. Asian J. Crop Sci., 3: 106-117.

Khaliq, I., M. Abbas and M. Asghar Rahim. (2001). Association of Morphological Characters with Economic Yield in Spring Wheat (Triticum aestivum L.). J. Biol. Sci., 1: 432-433.

Khalily, M., M. Moghaddam, H. Kanouni and E. Asheri. (2010). Dissection of Drought Stress as a Grain Production Constraint of Maize in Iran. Asian J. Crop Sci., 2: 60-69.

Khan, A. S. , M. Ashfaq and M. A. Asad. (2003). A Correlation and Path Coefficient

Analysis for Some Yield Components in Bread Wheat. Asian J. Crop Sci., 2: 582-584.

Khan, F.A., S. Ali, A. Shakeel, A. Saeed and G. Abbas. (2006). Correlation analysis of some quantitative characters in Brassica napus L. J Agric Res 44, 7-14.

Leilah, A.A., and S.A. Al-Khateeb. (2005). Yield analysis of canola (Brassica napus L.) using some statistical procedures. Saudi J. Bio. Sci., 12, 103-113.

Madson, E. (1976). Nuclear magnetic resonance spectrometry: A method of determination of oil content in rapeseed oil. J. Am. Oil Chem. Soc. 53:467-469.

Mahasi, M.J., R.S. Pathak , F.N. Wachira, T.C. Riungu, M.G. Kinyua and J.W. Kamundia. (2006). Correlations and Path Coefficient Analysis in Exotic Safflower (Carthamus tinctorious L.) Genotypes Tested in the Arid and Semi Arid Lands (Asals) of Kenya. Asian J. Crop Sci., 5: 1035-1038.

Marjanovic-Jeromela, A., R. Marjanovic, A. Mijic, Z. Zdunic, S. Ivanovska and M. Jankulovska. (2007). Correlation and path analysis of quantitative traits in winter rapeseed (Brassica napus L.). Agric. Con. Sci.73(1): 13-18.

Marjanovic-Jeromela A., A. Kondic-Spika, D. Saftic-Pankovic, R. Marinkovic. and N. Hristov. (2009). Phenotypic and molecular evaluation of genetic diversity of rapeseed (Brassica napusL.) genotypes. African Journal of Biotechnology, 8 (19): 4835-4844.

Ogrodowczyk, M. and M. Warzyniak. (2004). Adoption of the path-coefficient analysis for assessment of relationship and interrelationship of yield and yield parameters of winter oilseed rape. Rosliny Oleiste, 25 (2): 479- 492.

Miri, H.R. 2007. Morphophysiological basis of variation in rapeseed (Brassica napus L.) yield. Int. J. Agri. Biol., 9(5):701-706.

Sabaghnia, N., H. Dehghani, B. Alizadeh. and M. Mohghaddam. (2010). Interrelationships between seed yield and 20 related traits of 49 canola (Brassica napusL.) genotypes in non-stressed and water-stressed environments. Spanish J. . Agric. Res. 8(2), 356-370.

Sagir, A., B. T. Bicer and D. Sakar. (2004). Correlations among Characters and Ascochyta Blight Disease Severities in Chickpea Breeding Lines.Plant Pathology Journal,3:40-43.

Scheiner, S.M., R.J. Mitchell and H.S. Callahan. (2000). Using path analysis to measure natural selection. J. Evol. Biol., 13: 423-433.

Selvaraj, C. I. and P. Nagarajan. (2011). Interrelationship and Path-coefficient Studies for Qualitative Traits, Grain Yield and other Yield Attributes among Maize (Zea mays L.). Int. J. Plant Breed. Genet., 5: 209-223. 
Sharief A.E. and M.M. Keshta. (2002). Influence of sowing dates and plant density on growth and yield of canola(Brassica napus, L.) under salt affected soils in Egypt. Basic and Applied Sciences 3(1):65-78.

Siadat, S.A. and S.S. Hemayati. (2009). Effect of sowing date on yield and yield components of three oilseed rape varieties. Plant Ecophysiology 1:31-35.

Steel, R.G.D., J.H. Torrie, and D.A. Dickey. (1997). Principles and procedures of statistics. A biometrical approach. 3rd ed. McGraw-Hill, New York, NY.

Thurling, N. (1991). Application of the ideotype concept in breeding for higher yield in the oilseed brassicas. Field Crops Res., 26: 201-219.

Ullah, M.Z., M.K. Bashar, M.S.R. Bhuiyan, M. Khalequzzaman and M.J. Hasan. (2011). Interrelationship and Cause-effect Analysis among Morpho-physiological Traits in Biroin Rice of Bangladesh. Int. J. Plant Breed. Genet., 5: 246-254.

Wiliams, W.A., M.B. Jones and W. Demment. (1990). A concise table for path analysis statistics. Agron.J.,82: 1022-1024. 